\title{
Kandungan Klorofil Total Daun Pada Padi Lokal Sulawesi Utara Yang Mengalami Cekaman Banjir
}

\author{
Fitria Tjollenga* ${ }^{*}$ Parluhutan Siahaan ${ }^{{ }^{*}}$, Nio Song $\mathrm{A}^{\mathrm{a}^{*}}$ \\ aJurusan Biologi, FMIPA, Unsrat, Manado
}

\begin{tabular}{l} 
K A T A K U N C I \\
\hline Padi lokal \\
Cekaman banjir \\
Klorofil total
\end{tabular}

K E Y W O R D

Local rice,

Partial submergence

Total chlorophyll

\begin{abstract}
A B S T R A K
Penelitian ini bertujuan untuk mengkaji respon fisiologi tanaman padi lokal Sulawesi Utara (varietas Ombong, Temo, TB, dan Sultan) terhadap cekaman banjir pada fase vegetatif berdasarkan kandungan klorofil total pada daun. Pot dan tanaman padi dimasukkan ke dalam ember sehingga terendam setinggi $27 \mathrm{~cm}$ di atas permukaan media. Perlakuan cekaman kebanjiran berlangsung selama 20 hari. Pengambilan data dilakukan pada hari ke-0 (sebelum perlakuan), 10, 15 dan 20 setelah perlakuan. Daun diambil sebanyak $1 \mathrm{~g}$ kemudian dihaluskan dan diekstraksi menggunakan alkohol 95\% dan kandungan klorofil diukur dengan spektrofotometer. Data kandungan klorofil total dalam percobaan faktorial dianalisis dengan analisis sidik ragam dalam rancangan acak lengkap pada tingkat kepercayaan 95\%. Hasil penelitian ini menunjukkan bahwa faktor varietas, faktor waktu dan interaksi antara keduanya tidak menunjukkan perbedaan yang nyata pada kandungan klorofil total pada daun tanaman padi (varietas Ombong, Temo, TB, dan Sultan) selama 20 hari perlakuan cekaman banjir.

A B S T R A C T

This study examined the physiological responses of North Sulawesi local rice plants in (Ombong, Temo, TB, and Sultan varieties) to partial submergence at the vegetative phase based on the content of total chlorophyll in the rice leaves. The pot and plants were submerged under water in a bucket about $27 \mathrm{~cm}$ above the surface of the media. The submergence treatment was lasted for 20 days. Data collection was carried out at day 0 (before treatment), 10, 15 and 20 after treatment. The leaves (about $1 \mathrm{~g}$ for ach sample) were collected, then refined and extracted using 95\% ethanol. The total chlorophyll content was measured using spectrophotometer. Data of total chlorophyll content in the factorial experiment were analyzed using analysis of variance under completely randomized design at a 95\% confidence level. The results of this study indicated that variety and time factors as well as their interactions showed no significant differences in the content of total chlorophyll in the leaves of rice plant varieties (Ombong, Temo, TB, and Sultan) during 20 days of partial submergence.
\end{abstract}

TERSEDIA ONLINE

01 Agustus 2019

1. Pendahuluan

Tanaman padi (Oryza sativa L.) merupakan salah satu tanaman pangan yang telah menjadi makanan pokok yang sangat penting bagi lebih dari setengah penduduk dunia. Padi merupakan komoditas utama dalam mendukung kebutuhan pangan di Indonesia (Anggraini et al., 2013). Kandungan padi giling adalah karbohidrat $78,9 \%$, protein $6,9 \%$, lemak $0,7 \%$, dan lain-lain $0,6 \%$ (Poedjiadi, 1994).

Indonesia termasuk negara yang banyak mengalami hujan sehingga sering mengalami banjir dan genangan air. Banjir dan genangan air dianggap sebagai salah satu fenomena alam yang mengancam lahan pertanian, terutama di negaranegara yang memiliki dataran rendah luas (Verhoeven dan Setter, 2010). Banjir yang bersifat

*Corresponding author: Jurusan Biologi FMIPA UNSRAT, Jl. Kampus Unsrat, Manado, Indonesia 95115; Email address: niosongai@unsrat.ac.id Published by FMIPA UNSRAT (2019) 
sementara maupun terus-menerus merupakan salah satu cekaman abiotik utama yang menentukan reaksi adaptif tanaman dan juga produktivitas pertanian (Fan et al., 2015).

Banjir mengakibatkan hilangnya hasil pertanaman padi yang cukup besar sehingga petani mengalami kerugian dan masyarakat mengalami kekurangan kebutuhan pangan. Kondisi banjir pada lahan yang ditanami padi bervariasi mulai dari banjir dangkal dalam waktu yang singkat sampai pada banjir dalam waktu yang lama atau bulanan (Puslitbang Tanaman Pangan, 2009). Padi merupakan tanaman yang dapat beradaptasi pada kondisi tanah yang jumlah airnya berlebih, tetapi tanaman padi akan mati apabila seluruh bagian tanamannya terendam selama seminggu atau lebih (Ito et al., 1999).

Tanaman yang berada dalam kondisi terendam dalam waktu yang cukup lama akan menyebabkan tanaman mengalami penurunan jumlah klorofil (Wibisono, 2017). Perlakuan penggenangan pada tanaman tebu baik pada tebu hasil mutasi maupun tanpa mutasi menunjukkan rata-rata nilai kandungan klorofil lebih tinggi pada perlakuan tanpa penggenangan dibandingkan dengan ratarata hasil pada perlakuan penggenangan (Suliswanto, 2016). Hasil penelitian Rahayuningsih et al. (2013) menunjukkan bahwa pada varietas jagung Sukamaraga dan varietas Pioner 21 memiliki kecenderungan penurunan kadar klorofil a, klorofil b, dan klorofil total dengan semakin lamanya durasi genangan.

Data tentang kemampuan varietas padi lokal ini dalam merespon cekaman banjir yang ditinjau dari aspek fisiologis seperti kandungan klorofil masih sangat terbatas. Penelitian ini untuk mengkaji respon fisiologi tanaman padi lokal Sulut yang mengalami cekaman banjir berdasarkan kandungan klorofil total yang dilakukan pada fase vegetatif.

\section{Bahan dan Metode}

Penelitian ini dilaksanakan pada bulan November 2018 sampai dengan Januari 2019. Perkecambahan, pemeliharaan tanaman, dan pemberian perlakuan banjir dilakukan di rumah kaca di Kelurahan Tingkulu, Manado, Sulawesi Utara. Penentuan kandungan klorofil total, dilakukan di Laboratorium Ekologi Jurusan Biologi FMIPA, Universitas Sam Ratulangi. Bahan-bahan yang digunakan dalam penelitian adalah padi varietas Ombong, Temo, TB, dan Sultan, tanah, telur, garam, larutan pemutih komersial, etanol 95\%, pupuk NPK dan Gandasil-D, dan air.

Penelitian ini merupakan percobaan faktorial dalam rancangan acak lengkap dengan empat macam varietas padi (varietas Ombong, Temo, TB, dan Sultan) dan empat waktu pengambilan sampel sebelum perlakuan (hari ke-0), 10, 15, dan 20 hari setelah pemberian cekaman banjir.

Seleksi benih dilakukan dengan cara merendam benih padi di dalam larutan garam selama 2 jam yang bertujuan untuk mendapatkan benih padi yang berkualitas (modifikasi Nio dan Ludong, 2014). Benih padi disterilisasi menggunakan pemutih komersial 2\% (dengan bahan aktif 5,25\% $\mathrm{NaClO}$ ) selama 2 menit dengan tiga kali ulangan, lalu dibilas dengan air yang sudah dimasak dan benih direndam selama satu malam. Tahap berikutnya benih dikecambahkan di wadah yang berisi tanah. Media tanam beserta benih padi di wadah tersebut disiram dengan air sampai kapasitas lapang, kemudian bagian atas wadah ditutupi dengan kertas koran yang sudah dibasahi (modifikasi Nio dan Ludong, 2014).

Benih padi dari tiap varietas yang telah berkecambah ditanam pada media dalam pot botol air mineral dengan setiap botolnya ditanam 1 benih yang telah berkecambah dan bagian atas wadah ditutup dengan kantong plastik yang sudah dibasahi (modifikasi Nio dan Ludong, 2014). Pot botol air mineral yang telah berisi benih yang berkecambah disiram dengan campuran air dan pupuk (10 g pupuk Gandasil D dalam $10 \mathrm{~L}$ air) sampai kapasitas lapang setiap hari. Media yang digunakan berupa tanah campuran (tanah taman: pupuk kandang: sekam = 5:1:1), pupuk NPK dengan perbandingan dalam 6 g pupuk NPK dicampur dengan $7 \mathrm{~kg}$ tanah campuran (modifikasi dari Palit et al., 2015). Penyiraman dengan larutan pupuk ini dilakukan sampai tanaman mencapai tahap 4 daun yang berkembang penuh atau 4-fully-expanded leaf (modifikasi Nio dan Ludong, 2014) dan perlakuan kebanjiran dimulai.

Pot dan tanamannya dimasukkan ke dalam ember (diameter $47 \mathrm{~cm}$, tinggi $44 \mathrm{~cm}$ ) yang berisi air sehingga tanaman terendam setinggi $27 \mathrm{~cm}$ di atas permukaan media selama 20 hari. Pengambilan data untuk pengamatan dilakukan pada hari ke-0 (sebelum perlakuan banjir dimulai), 10, 15, dan 20 hari setelah perendaman (modifikasi Poluan et al., 2017).

Kandungan klorofil total pada daun tanaman padi lokal Sulawesi Utara sebagai respon fisiologis terhadap cekaman banjir ditentukan dengan cara:

1. Helaian daun sebanyak $1 \mathrm{~g}$ pada tiap perlakuan banjir diambil dan dihaluskan. Helaian daun yang telah halus diekstraksi dengan $50 \mathrm{~mL}$ etanol 95\% sampai semua klorofil larut.

2. Ekstrak tersebut disaring dan filtrat ditampung di dalam labu ukur $100 \mathrm{~mL}$ serta ditambahkan etanol 95\% sampai mencapai volume $100 \mathrm{~mL}$.

3. Kandungan klorofil diukur dengan menggunakan spektrofotometer pada $\lambda 649$ dan $665 \mathrm{~nm}$. Kandungan klorofil total dihitung dengan rumus berikut:

Klorofil total $(\mathrm{mg} / \mathrm{L})=20,0 \mathrm{OD}_{649}+6,1 \mathrm{OD}_{665}$ $(\mathrm{OD}=$ Optical density = Nilai absorbansi, Nio, 2017).

Data kandungan klorofil a, b, dan total dalam percobaan faktorial dianalisis dengan analisis sidik ragam dalam rancangan acak lengkap pada tingkat kepercayaan 95\% (Sastrosupadi, 2000). 


\section{Hasil dan Pembahasan}

Penelitian yang telah dilakukan ini untuk mengkaji kandungan klorofil total daun padi lokal Sulawesi Utara (varietas Ombong, Temo, TB, dan Sultan) terhadap cekaman banjir selama 20 hari pada fase vegetatif. Hasil analisis sidik ragam dengan taraf kepercayaan 95\% menunjukkan bahwa faktor lama perlakuan banjir, faktor varietas dan interaksi dari kedua faktor tersebut tidak menyebabkan perbedaan kandungan klorofil total (Gambar 1) yang nyata, sehingga tidak dilanjutkan dengan uji BNT (Beda Nyata Terkecil) 5\%.

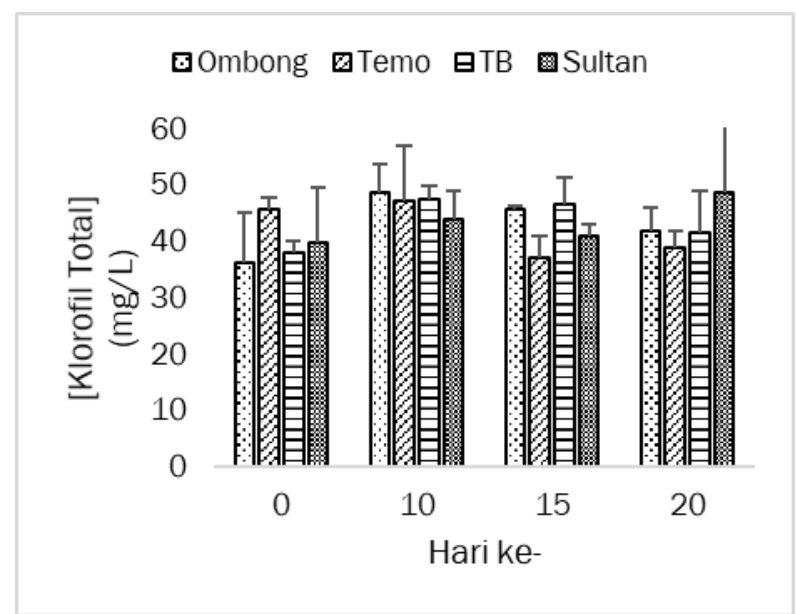

Gambar 1. Kandungan klorofil total (mg/L) pada daun padi varietas Ombong, Temo, TB, dan Sultan pada hari ke- 0, 10, 15 dan 20 setelah perlakuan banjir.

Kandungan klorofil total yang tidak berbeda nyata ini disebabkan oleh beberapa faktor, antara lain:

1. Tidak semua bagian tanaman padi terendam air.

Tanaman masih bisa bertahan dalam kondisi tercekam, karena daun tanaman padi yang berada di atas permukaan air masih bisa memperoleh cahaya matahari untuk proses fotosintesis. Padi merupakan tanaman yang dapat beradaptasi pada kondisi tanah yang jumlah airnya berlebih, tetapi tanaman padi akan mati apabila seluruh bagian tanamannya terendam selama seminggu atau lebih (Ito et al., 1999). Perlakuan banjir dalam penelitian ini dikategorikan partial submergence, karena yang terendam adalah sistem perakaran dan sebagian bagian tanaman yang berada di atas media tumbuh (Nio et al., 2019).

2. Cadangan pati yang tinggi pada tanaman padi.

Cadangan pati yang tinggi pada tanaman padi saat terendam menyebabkan daya tahan hidup padi yang lebih tinggi. Hal ini disebabkan karena cadangan pati tersebut dapat digunakan setelah diubah menjadi gula sederhana (Suwignyo, 2007).

3. Kondisi normoksia pada tanaman padi saat tercekam banjir.

Genangan pada tanah yang disebabkan oleh banjir dalam penelitian ini mengakibatkan pasokan $\mathrm{O}_{2}$ dalam kondisi normoksia yang masih memungkinkan tanaman untuk melakukan respirasi aerobik dan juga proses metabolisme secara normal serta sebagian besar ATP yang dihasilkan melalui fosforilasi oksidatif (Parent et al., 2013 dalam Nio dan Ludong, 2017).

4. Umur padi saat perlakuan banjir dimulai.

Jackson dan Ram (2003) menyebutkan bahwa tanaman padi yang masih muda biasanya lebih rentan terhadap cekaman banjir. Umur padi saat perlakuan dalam penelitian ini dimulai adalah 42 hari dan keempat varietas tanaman padi ini masih mampu mempertahankan diri terhadap cekaman banjir. Safrizal et al. (2008) melaporkan klorofil daun tanaman cabai TM-88 kontrol yang berumur 22 hari lebih tinggi dibandingkan dengan pada perlakuan GS (genang setengah) dan GP (genang penuh) selama 21 hari. Kandungan klorofil pada tanaman kontrol lebih tinggi karena pertumbuhan tanaman lebih baik dan unsur-unsur yang berperan dalam pembentukan klorofil tersedia dalam jumlah yang lebih banyak dibandingkan dengan tanaman yang mengalami penggenangan.

5. Durasi perlakuan banjir pada tanaman padi

Waktu perlakuan cekaman banjir dalam penelitian ini hanya 20 hari dan belum mempengaruhi kandungan klorofil total daun. Perlakuan 50 hari genangan pada bibit tanaman kelapa sawit (Elaeis guineensis Jack) berpengaruh sangat nyata terhadap kandungan klorofil. Penggenangan dalam periode panjang menyebabkan perubahan morfologi akar, sehingga penyerapan unsur-unsur hara akan terganggu dan tanaman akan mengalami kekurangan unsur-unsur hara serta daun tanaman mulai menguning. Daun yang menguning disebabkan oleh rusaknya klorofil atau disebabkan terhambatnya pembentukan klorofil akibat terganggunya aktivitas sel (Warjianto, 2014).

\section{Kesimpulan}

Faktor varietas, faktor waktu dan interaksi antara faktor varietas dan waktu tidak menyebabkan perbedaan kandungan klorofil total yang nyata pada varietas tanaman padi (Ombong, Temo, TB, dan Sultan) yang mengalami 20 hari cekaman banjir. Tidak adanya perbedaan kandungan korofil total ini berkaitan dengan tidak semua bagian tanaman padi terendam air, cadangan pati yang tinggi pada tanaman padi, kondisi normoksia pada tanaman padi saat tercekam banjir, umur padi saat perlakuan banjir dimulai, dan durasi perlakuan banjir pada tanaman padi..

\section{Daftar Pustaka}

Anggraini, F., Agus, S., dan Aini, N. 2013. Sistem Tanam dan Umur Bibit pada Tanaman Padi Sawah (Oryza sativa L.) Varietas Inpari 13. Jurnal Produksi Tanaman 1(2): 52-60.

Fan, Y., Chunyu, H., Zhen, L., Yangnan, G., and Zhulong, C. 2015. Dissecting Tissue and Specific Responses of Two Plantago Species to 
Waterlogging Stress at Physiological Level. Enviromental Experiment Botany 109: 177-185.

Ito, O., Ella, E., and Kawano, N. 1999. Physiological Basis of Submergence Tolerance in Rainfed Lowland Rice Ecosystem. Field Crops Research 64: 75-90.

Nio, S.A. 2017. Fisiologi Tumbuhan dalam Praktek. C.V. Patra Media Grafindo. Bandung.

Nio, S.A. dan Ludong, D.P.M. 2014. Comparing the Drought Tolerance of Local Rice Cultivar Superwin with other Cultivars Cultivated in North Sulawesi Province Based on Dry Matter Partitioning. Proceding International Conference on Global Resource Conservation 4(1): 17-22.

Nio, S.A. dan Ludong, D.P.M. 2017. Ekofisiologi Tumbuhan. CV. Patra Media Grafindo. Bandung.

Nio,S.A., Siahaan, R. dan Ludong, D.P.M. 2019. Partial Submergence Tolerance in Rice (Oryza sativa L.) Cultivated in North Sulawesi at The Vegetative Phase. Pakistan Journal of Biological Sciences 22(2):95-102.

Palit, E.J, Nio, S.A., dan Mantiri, F.M. 2015. Pelayuan Daun pada Padi Lokal Sulut Saat Kekeringan. Jurnal MIPA Online 4(2):120-124.

Poedjiadi, A. 1994. Dasar-Dasar Biokimia. Universitas Indonesia. Jakarta.

Poluan, R.H., Nio, S.A., dan Mantiri, F.M. 2017. Evaluasi Tahan Banjir Padi Lokal Sulut pada Fase Vegetatif dengan Variasi Waktu Perendaman. Jurnal IImiah Sains 17(1):1-6.

Pusat Penelitian dan Pengembangan Tanaman Pangan. 2009. Deskripsi Varietas Unggul Padi 1943-2009. Badan Penelitian dan Pengembangan Pertanian. Bogor

Safrizal, Santosa, E., dan Bakhtiar. 2008. Pengaruh Penggenangan Terhadap Pertumbuhan Vegetatif Cabai. J. Floratek. 3: 61-67.

Sastrosupadi. 2000. Rancangan Percobaan Praktis Bidang Pertanian. Edisi Revisi. Penerbit Kanisius. Jakarta.

Suliswanto, E. N. 2016. Identifikasi Mutan Tebu (Saccharum officinarum L.) Toleransi Genangan [Skripsi]. Fakultas Pertanian. Universitas Jember.

Suwignyo. R.A. 2007. Ketahanan Tanaman Padi terhadap Kondisi Terendam: Pemahaman terhadap Karakter Fisiologis untuk Mendapatkan Kultivar Padi yang Toleran di Lahan Rawah Lebak. Kongres IImu Pengetahuan Wilayah Indonesia Bagian Barat. Palembang, 3-5 Juni 2007.

Verhoeven, J.T.A., and Setter, T.L. 2010. Agricultural Use of Wetlands: Opportunities and Limitations. Annual Botany 105: 155-163.

Warjianto, 2014. Respon Pertumbuhan Bibit Tanaman Kelapa Sawit (Elaeis guineensis Jack) Main Nursery terhadap Perlakuan Lama Genangan [Skripsi]. Fakultas Pertanian. Universitas Musi Rawas. Lubuklinggau. Sumatera Selatan.

Wibisono, I. 2016. Analisis Molekuler BC2F1 Hasil Silang Balik Genotipe Padi Rawa Terpilih
Dengan Metode Marker Assisted Backcrossing (MABc) [Tesis]. Fakultas Pertanian. Universitas Sriwijaya. 